\title{
EFFECTIVENESS EVALUATION OF SERVICE PROVIDED IN GEOLOGY: INTRODUCTION OF A PILOT PROJECT EES $_{\mathrm{G}}$
}

\author{
MARKÉTA LAJCZYKOVÁ
}

\section{EFFECTIVENESS AND ITS SIGNIFICANCE}

With the development in sphere of quality management of companies have already today recognizes that quality could be considered as a limiting factor for the so-called sustainable development of the organization. It is known, that the problems of productivity are associated with poor quality in most cases. Quality management system is currently applied in many supplier chains and business chains and represents a further limits of competition on the market.

Declaration of the quality importance in a competitive market environment can verify by result of the recent analysis. This analysis was focused on competitive advantage through systems management (SM). The analysis was performed in a specific organization for the period 2006-2009. The analysis was based on dissection of won and not-won orders (contracts), which include the requirement for management systems in tenders. The analysis presented the impact on the final financial volume.

During the period under review was received 498 inquiries. Of these inquiries included the demand for systems management 267 inquiries. Therefore, the SM requirement contains $54 \%$ of inquiries.

In appreciation of realized orders with regard to the requirements of their SM and financial volume was found, that $80 \%$ of the financial volume of contracts applies to contracts requiring SM, as illustrated in Figure 1. 


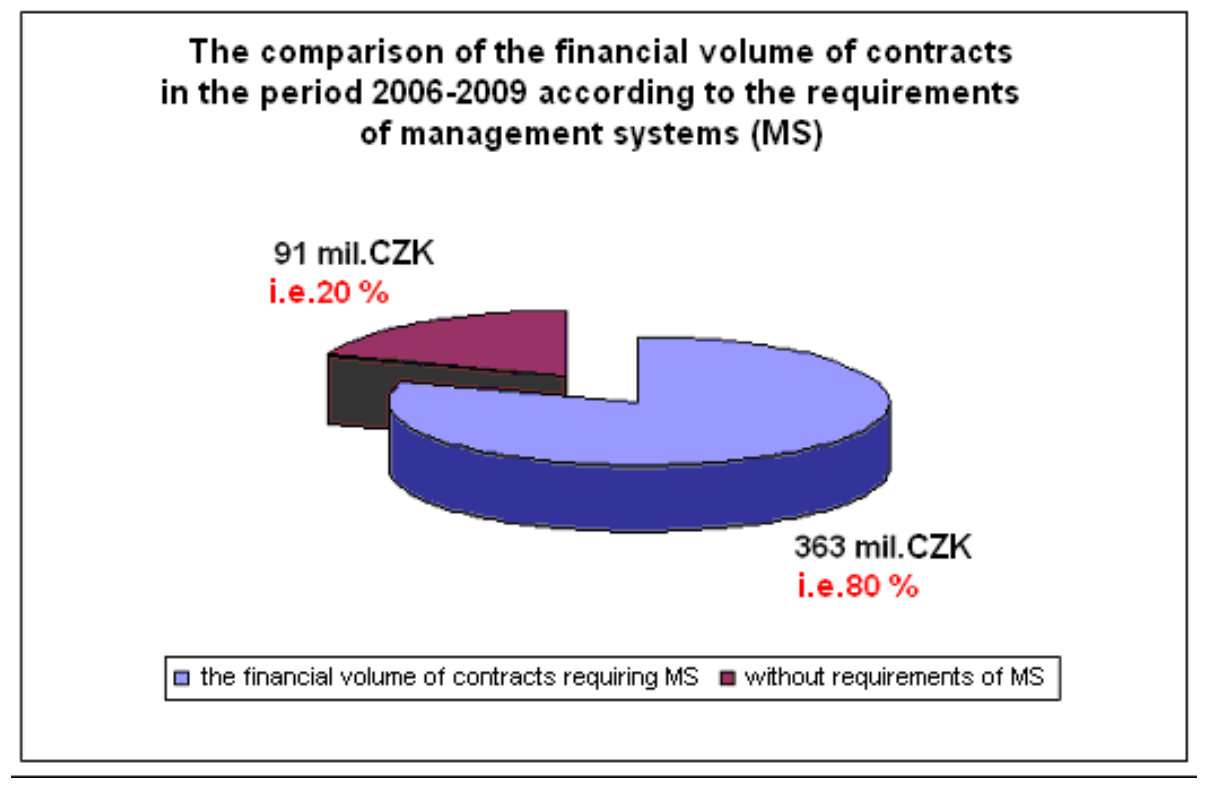

Figure 1- Chart illustrate the financial volume of orders (contracts) in the period 2006-2009 according to the an unspecified SM requirements

The unspecified SM requirement means claim on management system, regardless of the orientation (QMS, EMS or H§SMS). Analysis of the concrete SM requirements is illustrated in Table 1.

Table 1 - Dependence of the contracts financial volume on the specific SM requirements in the period 2007-2009

\begin{tabular}{|c|c|c|c|}
\hline financial volume & QMS & $\begin{array}{c}\text { QMS + } \\
\text { EMS }\end{array}$ & $\begin{array}{c}\text { QMS + } \\
\text { EMS + } \\
\text { H\&SMS }\end{array}$ \\
\hline to 50 000 CZK & 2 & 1 & 3 \\
\hline 50 000 - 500 000 CZK & 3 & 2 & 20 \\
\hline $500000-1$ million CZK & 7 & 4 & 7 \\
\hline 1 - 10 million CZK & 10 & 15 & $\mathbf{5 0}$ \\
\hline over 10 million CZK & 2 & 8 & $\mathbf{3 2}$ \\
\hline
\end{tabular}

Note: The figures in this table correspond to the number of inquiries with this requirement. Separate EMS requirement, H§SMS requirement, EMS-H§SMS requirement or QMS-H§SMS requirement has not been registered in the period under review.

The number of received inquiries (which contains a SM requirement) shows, that establishing and maintain to management systems mean "half success" for the 
organization when entering competitions. The analysis also revealed that more kinds of management system is a "ticket" to financially bulkier and more significant longer-term contracts. The management system is not only an important "plus", but can be said "a vital factor" in the most competitive in the market.

The quality of the process depends on the resulting customer satisfaction and process performance (Fiala et all, 2008). Turning now to the process performance evaluation, or even closer to the effectiveness evaluation, which includes performance evaluation among others. The phrase "Effectiveness evaluating" presents determining of the extent, where are realized planned activities and achieved planned results (Fiala et all, 2008). It includes quantifiable factors (for example by performance evaluating of the indicators) and unmeasurable factors (for example rated only by the workgroup). Management of organization have to be able to effectiveness evaluate of its processes, to be able to specify the direction of process development to achieve quality improvements and the related productivity improvements.

This paper is focused on providing services, specifically for Effectiveness Evaluating of Services in the Field of Geology (project acronym: $E_{E S}$ ). It delivers the introduction of a pilot project to establish a general methodology for effectiveness evaluating of services in the field of geology. This project use several methods from field of quality management system for analyzing data and is solved in practice in surroudings of a specific organization.

\section{PLAN OF THE EFFECTIVENESS EVALUATION OF SERVICE PROVIDED}

Effectiveness evaluation of intangible products, specifically the provision of services, can be performed by using methods of quality management system. Effectiveness evaluation of providing services process is a very important factor in deciding in this process control and contributes to the so-called operational quality management, which includes the operating methods and activities aimed at process monitoring and removing the causes of the defective outcomes and weaknesses (Tošenovský et all, 2008). Just as the concept of service is variable, is effectiveness evaluating of the services variable too, such as product of organization.

The product is defined as a result of the process, which means that the product can be both product and service. Intangible result of a process is a "service". This project is focused on the special services in the field of geology and way of the evaluation of their effectiveness. Primary concern is define a clear methodology for effectiveness evaluation of services focusing on geology based on survey methods of data analysis in the quality. Accompanying effect is the research, which goal is improving the way of effectiveness evaluating of the services provided under a certified quality management system based on testing. For the 
development of methods for effectiveness evaluating of services in the field of geology could be used familiar tools of quality management.

The basic practical aim is improving of the providing services process control. Foundation of success for determining an appropriate method is its practical application to individual contracts of a specific organization with the aim to effectiveness evaluate of the realization of contracts. Prerequisite for the direct impact of $\mathrm{EES}_{\mathrm{G}}$ in practice is processes improving associated with improving of its position in competition in the market. This project should create an environment for continuous improvement and optimizing the process of providing services. Finally, the project should minimize costs associated with this process. Ultimately, you can expect a positive impact on customer satisfaction and loyalty. Because of those impacts this project may be categorized as performance measurement systems in quality management (Nenadál, 2001).

To create the basic parameters for $\mathrm{EES}_{\mathrm{G}}$ can use many of the tools of quality management system. In this case could be examined using methods CEDAC (Cause and Effect Diagram with Additional Cards). Application of CEDAC methodology in unknown providing service field in the rank of geology could help in establishing some basics of the methodology $\mathrm{EES}_{\mathrm{G}}$.

\section{SERVICES IN THE FIELD OF GEOLOGY}

For proper initiation of the project $\mathrm{EES}_{\mathrm{G}}$ is important to allocate exact scope of activities for aplication in project $\mathrm{EES}_{\mathrm{G}}$. Those categories of activities and the exact scope of activities should be addressed by negotiation with the leadership of the organization. In this case a scope of activities was solved by workshops and is only informative yet, because project-team is still discussing the breadth of other processes, which can be involved in the project. Workshop was implemented with management of professional Division No.1, and determinined the scope and haromonogram of project progress. Furthermore, is preparing the workshop with a professional Division No. 2, especially the possible applications in geotechnical surveys for construction courses, and study the possibility of involvement of the professional Division No. 3 in the project, particularly in the area of drilling works.

For better clarity and more precise definition the categorization of three ways is chosen.

\section{Description of activities according to product category}

Interested organization provide services as a result of at least one activity necessarily performed at the interface between suppliers and customers. Service is in the result a intangible, even though it may include sub-products of mixed character, that is both tangible products and intangible products (Fiala et all, 
2008). Many different contracts can in practice include a combination of several categories of activities, as illustrated Table 2.

Table 2 - Description of the activities according to product categories

\begin{tabular}{|c|c|}
\hline $\begin{array}{c}\text { Category } \\
\text { number }\end{array}$ & \multicolumn{1}{|c|}{ Description of the category / list of relevant activities } \\
\hline Category I. & $\begin{array}{l}\text { Activity conducted on the tangible product supplied by the } \\
\text { customer }\end{array}$ \\
\hline $\begin{array}{l}\text { Remediation of soil or groundwater contaminated especially in the industrial } \\
\text { estates (for example hydrogeology and geochemistry). }\end{array}$ \\
\hline Category II. & $\begin{array}{l}\text { Activity conducted on an intangible product shipped by the } \\
\text { customer }\end{array}$ \\
\hline Processing and evaluation data of water and soil laboratory analysis. \\
\hline Category III. & Intangible product supplies \\
\hline $\begin{array}{l}\text { Processing geological projects and final reports, consulting in the field of } \\
\text { geology, engineering, etc. }\end{array}$ \\
\hline
\end{tabular}

\section{Description of the activities according to expert fields division}

1) Geology

2) Industrial ecology (especially sanitation geology)

3) Experts and assessment activities in the field of geological disciplines

\section{Description of activities under CZ-NACE}

Scope of service activities in the field of geology can be defined on the basis of "CZ-NACE", as illustrated Table 3. CZ-NACE categorizes activities according to the data associated with the economic subject - the organization. Classification according to "CZ - NACE" is chosen, because only the "CZ-NACE codes" define the accreditation scope of certification body for certification of management systems in each organization.

Engineering activities and related technical consulting services includes for example: projects related to constructional engineering, water and road structures, water-control projects, designing projects using environmental technology and pollution control, geological surveys, hydrological mapping, etc.

During project implementation can be the scope of activities changed according to the results of further discussions and decision of the management. 
Table 3 - Description of the activities according to CZ-NACE.

\begin{tabular}{|c|l|}
\hline $\begin{array}{c}\text { CZ NACE } \\
\text { code }\end{array}$ & \multicolumn{1}{|c|}{ Activities description } \\
\hline 39.00 & Remediation activities and other activities related with waste \\
\hline 42.91 & Construction of water projects \\
\hline 43.13 & Prospect drilling operation \\
\hline 71.12 & Engineering activities and related technical consultancy \\
\hline 71.12 .1 & Geological survey \\
\hline 71.12 .9 & $\begin{array}{l}\text { Other engineering activities and related technical consulting } \\
\text { services nec. }\end{array}$ \\
\hline 71.20 & Technical testing and analysis \\
\hline 74.90 & Other professional, scientific and technical activities nec. \\
\hline
\end{tabular}

\section{EES $_{\mathrm{G}}$ PROJECT}

EES $_{\mathrm{G}}$ project (Effectiveness Evaluation of Services in the field of Geology) involves just developed tool, its prototype will be applied in the real organization.

The general basis for effectiveness evaluation of each process is the identification of indicators for monitoring, measuring and consequently analyzing data about the product (service). Proper identification of indicators is the basis for the final effect. Indicators for monitoring and measurement, thus the quality features, can be determined by using the known methods, such as CEDAC (Cause and Effect Diagram with Additional Cards). CEDAC is transformed (advanced) form of Ishikawa diagram - fishbone diagram. Basic information about CEDAC, see section No.6. This methodology is mainly used by organizations, whose products are tangible (manufacturing organization). In the $\mathrm{EES}_{\mathrm{G}}$ project should be CEDAC experimentally applied in the filed of service, which may excite the modification necessity of the procedure in order to meeting project intentions.

In the case of $\mathrm{EES}_{\mathrm{G}}$ should be used this method to define indicators, that could lead to the effects of reducing or increasing effectiveness of the process.

With the additionnal cards of CEDAC can not define only the indicators for monitoring and measurement (this means "what to measure"), but also other factors (such as "wherewithall to measure", "how to measure", "measurement period", etc. (Zgodavová et all, 2002). This is essential for building a next step of methodology - the establishment of an "inspection plan". "Inspection plan" should be established based on specified indicators for measure the product, but can be used for evaluation (monitoring) immeasurable indicators too. "Inspection 
plan" exactly defines implementation of monitoring, measurement and evaluation of the contract. On an "Inspection plan" concures so-called "Service effectiveness card" (definition below). By using CEDAC is possible to define the desired outcomes of the "Inspection plan" (strategy management) and monitoring can evaluates differences between the planned execution and final results (it follows from the definition of efficiency). In many cases occure changes in customer requirements during the realization of contract (extra works, etc.). By repeatedly creating of "Inspection plans" for individual contracts can be defined the specific improvement proposals based on previous results.

Before evaluating obtained information is necessary to determine the weight of each indicator, because each indicator has its own specifics and different effect on the final outcome of the process. Weight evaluation of indicators should be part of the so-called "Service efficiency card", which concures the filled "Inspection plan". The card should contain an appropriate function for determining the effectiveness of services, which have to include all the measured or assessed variables and their weight. "Service effectiveness card" should be quantitative characteristics of services provided efficiency on the basis of data from monitoring and measuring according to the "Inspection plan".

"Services efficiency card" is only a partial document for each contract from the cycle of long-term monitoring of contracts and serves as a basis for annual and overall comparison.

\section{ANALYSIS OF PROBLEM AREAS}

To create an appropriate "Inspection Plan" and "Service effectivenes card" is essential detailed study of processes. The basis is the processes analysis for their involvement in the project and subsequently structures creation of the "Inspection Plan" and "Service effectiveness card". In other words, the essence of the $\mathrm{EES}_{\mathrm{G}}$ project is studies of processes, that are interconnected in the system. One of the possibilities for the process analysis according to system-perspective is the analysis of the internal and external audits results of the organization.

For $\mathrm{EES}_{\mathrm{G}}$ project was this analysis performed in a concrete organization based on the audits results for the years 2002-2009. The objective is the identification of problem areas within the quality management system of the organization. This analysis is one of the bases and sources of information for creating "Service effectiveness card". Analysis results are internal property of the organization and therefore aren't presented in this paper in full scope. For the purposes of this paper may be presented the analysis conclusions (analysis was made in an organization, where is the $\mathrm{EES}_{\mathrm{G}}$ project implemented), as follows:

The analysis was divided into two evaluation. Frequency analysis represent evaluation of the areas, where are most frequently mistakes and inclinations from the standards. The analysis uses a graphical representation of the frequency of findings according to specific standard requirements (without taking due note of 
the weights of findings as the degree of significance). Importance-evaluation uses the so-called index number, this means, that this analysis takes due note of both the frequency and weight of the findings. This analysis focuses more on problem areas related to systemic solutions.

Conclusion of the frequency analysis indicates problematic areas (in relation to areas of the system according to standard ISO 9001:2008), where finely, but most frequently make mistakes ordinary workers.

In the area, with the high frequency of findings, was concluded that the problem is too often repeated controling of reports, which deal with a series of standards requirements (individual standard's articles). These findings are often caused by a one-off omissions or caused by human error (either ignorance, inconsistency, or lack of practice). The findings occurring in this area deal with those parts of the processes, which involve the largest range of employees and where are generally prescribed the responsibility of type: "everyone have to respect". In the future the removing of this problems can be achieved by increasing awareness of the seriousness in adherence to the internal standards requirements, more frequently staff coaching in different subjects of knowledge, but also the tightening of controls and giving his own example (this means management responsibility), etc. Here is way of the improving clarity. Improvements in this area is neccesary for reinforcement the stability and efficiency of the system.

Conclusion of the importance-evaluation is, that in the identified critical areas is fault more serious and its solution will consist in examining the current system settings and searching new more suitable methods. In presenting the results should be emphasized that importance-evaluation results represent systemic perspective (taking due note of the findings significance).

The critical areas were showing requirements under articles of standard ISO 9001:2008 No. 7.1 "planning of product realization" and No. 8.2.3 "monitoring and measurement of processes". In the article No. 7.1 are especially incorrectness of production plans (worksheets, instructions, etc.) or their absence. The deficiency is serious, because the owner of the process has imperfect or doesn't have the proper standard. Findings from the article No. 8.2.3 show that once again neglected the basics of monitoring and measurement system. Requirements according to the article No.8.2.3 appear to be difficult to understand in many organizations in practice. One reason is that employees often don't understand the importance or the process to meet the requirements of article No. 8.2.3. Proper establishment and implementation of this requirements according to this article should be a source of valuable data for improving the QMS in the organization. Therefore they often regards monitoring as "unnecessary" or as a "waste of time".

The importance-evaluation result shows the areas, where should be focus on finding other more appropriate methods for setting these processes. Here should be selected the more complex corrective action. For the eliminate any obstacles during the application of $\mathrm{EES}_{\mathrm{G}}$ project, it would be appropriate when selecting 
tools to improve focus both on targeted improvements in existing processes and on improvements of the degree of employee involvement. In response to the finding deficiencies according to the article No.8.2.3 is being prepared mentioned $\mathrm{EES}_{\mathrm{G}}$ project.

\section{CEDAC - APPLICATION, INSPIRATION}

In the case of the exercise CEDAC, it is necessary to be well acquainted with the method. The source of information may be, inter alia, Dr. Ryuji Fukuda's publication "CEDAC a Tool for Continuous Systematic Improvement" (Fucuda, 1989).

CEDAC system (Cause and effect diagram with additional cards) is modified (more advanced) form of Ishikawa diagram - fishbone diagram. Ishikawa diagram is a tool for analyzing the causes of the concequences, which can be a corrective or preventive tool. This method uses a teamwork based on the brainstorming to maximize intellectual potential of employees.

CEDAC system can be applied to any area where are needed improvements, not only to the areas related to quality management. Employee management and employee training can be defined as the two most important factors for the development of an favorable environment conducive to continuous improvement. Favorable environment occurs when are met two conditions: 1. Proper practices (standards) have to be established, respected and practiced, 2. All stakeholders have to understand these procedures and manage them in practice accurately. There is another condition for improving success by Dr.Fukuda, involvement of employees in improvement process, which is (how the analysis of the audits in a specific organization revealed) just one of the identified problems.

CEDAC system structure consists of three processes (stages): Window Analysis, CEDAC diagram and the Window Development.

Window Analysis ( $1^{\text {st }}$ CEDAC stage) is used for the analysis of specific data on different nonconforming results and for categorization of the data according to their management. Window analysis structure consist of a diagram, in which are compared people, or functional groups that interact on himself daily at work. For categorization of data is used categories "Known", "Unknown", "Practiced", "Unpracticed". According to these categories the data and the related situation are categorizing to the basic categories A - D. With a focus on systemic perspective, the category "known" can be divided on the category "established" (known-established standard) and "known" (employees know the standard employees are familiar with standard). Each categories presents table 4. 
Table 4 - Categorization of situations

\begin{tabular}{|c|c|c|c|}
\hline 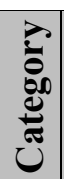 & $\begin{array}{l}\text { Description of undesirable event } \\
\text { (situation) }\end{array}$ & $\begin{array}{l}\text { Nature of the } \\
\text { situation }\end{array}$ & $\begin{array}{l}\text { Recommended } \\
\text { procedure }\end{array}$ \\
\hline $\mathbf{A}$ & $\begin{array}{l}\text { Proper procedures are established } \\
\text { and stakeholders know and } \\
\text { practice procedures correctly. } \\
\text { ESTABLISHED -KNOWN - } \\
\text { PRACTICED }\end{array}$ & Ideal situation & Not necessary \\
\hline $\mathbf{B}$ & $\begin{array}{l}\text { Procedures aren't practicing } \\
\text { correctly: careless mistakes, lack } \\
\text { of skills, lack of time,manpower } \\
\text { or financial resources). } \\
\text { ESTABLISHED -KNOWN - } \\
\text { UNPRACTICED }\end{array}$ & $\begin{array}{l}\text { The problem } \\
\text { with practice }\end{array}$ & $\begin{array}{l}\text { 1. Window } \\
\text { Deployment } \\
\text { 2. CEDAC Diagram } \\
\text { 3. Tools for preventing } \\
\text { human errors } \\
\text { 4. Tools for } \\
\text { improvement employee } \\
\text { skills, etc. }\end{array}$ \\
\hline $\mathrm{C}$ & $\begin{array}{l}\text { Procedures are established, but } \\
\text { they are unknown for interested } \\
\text { employees. }\end{array}$ & $\begin{array}{l}\text { The problem } \\
\text { with } \\
\text { comunication }\end{array}$ & $\begin{array}{l}\text { 1. Window } \\
\text { Deployment } \\
\text { 2. CEDAC Diagram } \\
\text { 3. The visual control } \\
\text { systems } \\
\text { 4. Daily management } \\
\text { system }\end{array}$ \\
\hline D & $\begin{array}{l}\text { Proper procedures aren't } \\
\text { established. } \\
\text { NOT ESTABLISHED - } \\
\text { UNKNOWN-UNPRACTICED }\end{array}$ & $\begin{array}{l}\text { The problem } \\
\text { with } \\
\text { standardization }\end{array}$ & 1. CEDAC Diagram \\
\hline
\end{tabular}

All situations filled into categories B, C and D according to the Window analysis must be transformed into the category A by the appropriate management.

For the purpose of this $\mathrm{EES}_{\mathrm{G}}$ project is expected situation in category $\mathrm{D}$, where the correct standard for effectiveness evaluating isn't established, is unknown and not yet practiced. Therefore may be to develop effectivnes evaluating methods (in the service sector) start from CEDAC diagram. 
CEDAC Diagram ( $2^{\text {nd }}$ CEDAC stage $)$ was created to solving problems in category D (where reliable method has not been established). CEDAC Diagram can be effectively applied also to weaknesses in category B or C. The CEDAC Diagram is a tool aimed at creating "standard". In the case of the $E \mathrm{SS}_{\mathrm{G}}$ project that means at creating standard for effectiveness evaluating. The basic feature of the diagram is the involvement of employees. To create CEDAC Diagram is essential determination of the working team. Team consists of employees from the different organizational levels (management, technicians, managers, operators, etc.) It means, that in this project work both people, who know the process, and people, who know the theoretical foundations of the methodologies and tools of quality. Of course it has a team named team leader. CEDAC diagram is similar with Ishikawa diagram, but the goal of CEDAC diagram is different. CEDAC Diagram goal is to find an effective system for creating standards, that eliminate the differences caused by the absence of reliable methods and procedures. CEDAC diagram can be interpreted in several steps, which are briefly described below. By CEDAC is determined subject for improvement, are determined his measurable outcomes and is set the time range for data collection. Further is defined the goal of improvement or assumptive benefit after achieving the goal. In the next step the obstacles are defined in achieving the goal. These are written on a so-called "fact cards" and subsequently are submitted the improvement ideas. The improvement ideas are documented on the "improvement cards", which are further categorized as "unusable", "of interest", "under preparation" or "under test". When are the improvement cards tested, the color description of each card is used, depending on the attached category, as ilustrated Table 5.

Table 5 - CEDAC Diagram Improvement cards categories

\begin{tabular}{|l|l|l|}
\hline \multicolumn{1}{|c|}{ Category } & \multicolumn{1}{|c|}{$\begin{array}{c}\text { Charakteristic of improvement } \\
\text { card }\end{array}$} & \multicolumn{1}{|c|}{ Colour description } \\
\hline „unusable“ & $\begin{array}{l}\text { Improvement idea isn't sufficient, or } \\
\text { is ineffective. }\end{array}$ & $\begin{array}{l}\text { The card doesn't } \\
\text { identify }\end{array}$ \\
\hline „of interest“ & $\begin{array}{l}\text { Improvement idea cannot be } \\
\text { implemented immediately. }\end{array}$ & $\begin{array}{l}\text { The card indicates a red } \\
\text { dot }\end{array}$ \\
\hline „under \\
preparation“ & $\begin{array}{l}\text { Improvement idea will be realized. } \\
\text { The tools, equipment, resources etc. } \\
\text { ere planning. }\end{array}$ & $\begin{array}{l}\text { The card indicates the } \\
\text { two red dots }\end{array}$ \\
\hline „under test“ & $\begin{array}{l}\text { Improvement ideas are tested and } \\
\text { the results monitored. }\end{array}$ \\
\hline
\end{tabular}


This scoring cards in the CEDAC Diagram allows instant overview about the state of improvment ideas during the project. If positive results are confirmed, the improvement idea is put into practice - from "improvement card" has become a "standard card".

The last process in the CEDAC structure is a "window development" $\left(3^{\text {rd }}\right.$ CEDAC stage), which examines the particular steps of a CEDAC Diagram and focuses on compliance with standards. In other words, this tool is designed to ensure, that every employee correctly understands and respects standard. "Window development" using numerical method for effectiveness evaluating of the standard based on classification on points of individual performance of submeasures corective action.

Posted proper understanding of the methods CEDAC in $\mathrm{EES}_{\mathrm{G}}$ project lies in the fact, that by its appropriate use should be properly set the parameters for $\mathrm{EES}_{\mathrm{G}}$ and so directly affect the success of $\mathrm{EES}_{\mathrm{G}}$.

CEDAC diagram would be presented in many literature separately. It can be used by using the Six Sigma method - CEDAC is there placed together with other methods as a tool, that examines the impact of inputs variability to outputs variability in the process and divided the various causes generally into several categories. In this case is described only CEDAC Diagram as an alternative approach (without the use of the successive steps according to Dr.Fukuda) and is displayed on a wall or a wide area and staff are encouraged to identify causes for example by using sticky notes. The success of this approach is seen in relation to organizational culture and communication " (Munro, 2007).

Publication "Quality Professional" (Zgodavová et all, 2002) states, that CEDAC is a tool developed to find an effective system of reliable standards and its main purpose is the elimination of serious disagreements caused by the absence of reliable methods.

\section{CONCLUSION}

Result of the $\mathrm{EES}_{\mathrm{G}}$ project should be a simple methodology for monitoring and measuring indicators of services in the field of geology, evaluation of the resulting values of efficiency. Assumed to use a combination of methods relating to the analysis in quality management system, rather than strictly as we know from literature, but adapted to the needs. The output should be the form or set of forms so-called "inspection plans" and "service effectiveness cards" to include both quantitative and qualitative data in the table- or graph forms with a final evaluation of the resulting efficiency. This resulting efficiency designate an area for specifying improvement ideas. Assumed to take corrective action, preventive action and improvement action during detection and evaluation of services. Also is expected visible improvement in the comparison of infra-annual evaluation and overall evaluationt. $\mathrm{EES}_{\mathrm{G}}$ project should also contribute to scientific 
knowledge by applying the CEDAC methodology (or by inspiring with CEDAC) in services in the field of geology.

\section{REFERENCES}

Fiala, A., Becková, M., Babinec, F., Bumbálek, L., Čepera, M., Dvořák, J., Fránek, P., Hřebíček,V., Just, K., Kostelka, A., Koška, P., Kotovicová, J., Lacko, B., Legát,V., Maroš, B., Němec, F., Poprach, I., Rajlich, J., Starzyczná, H., Ševčík, R., Tesák, M., Vršková, P., Zeman, J. (2008), Management procesů prưvodce manažera kvality. Verlag Dashöfer, ISSN 1802-1697.

Fucuda, R. (1989), CEDAC, A Tool of Continuous Systematic Improvement, Productivity Press, Inc. USA, ISBN 0-915299-26-7.

ISO 9000:2005 Quality Management System - Fundamentals and vocabulary, Edition: 3 | Stage: 90.93 | TC 176/SC 1.

ISO 9001:2008 Quality Management System - Requirements, Edition: 3 | Stage: 90.93 | TC 176/SC 2 ICS: 03.120.10.

Nenadál, J. (2001), Měrení v systémech managementu jakosti, Management press, Praha, ISBN 80-7261-054-6.

Roderick A., Ph. D. Munro, Maio, Mj. J., Nawaz, M. B., Ramu, G., Zrymiak, D. J. (2007), The Certified Six Sigma Green Belt Handbook (e-Book), ASQ quality Press, ISBN: 087389698X.

Tošenovský, J., Plura, J., Petříková, R., Noskievičová, D., Nenadál, J. (2008), Moderni management jakosti Principy, postupy a metody, Management Press, ISBN 978-80-7261-186-7.

Zgodavová, K., Linczényi, A., Nováková, R., Slimák, I. (2002), Profesionál kvality, TU Košice, ISBN 80-7099-669-2. 


\section{ABOUT THE AUTHOR}

Markéta Lajczyková was graduated from the Technical University of Ostrava, Czech Republic, Faculty of Mining and Geology, the field of study Environmental engineering. For several years she acts as a manager of an integrated management system for quality, environment and health and safety management in the prestigious geological organization UNIGEO a.s. in the Czech Republic. There she also acts as an internal auditor. She is certified by an external auditor for QMS and EMS. Currently studying PhD studies at the Technical University of Ostrava (scientific advicer prof. Kristína Zgodavová, $\mathrm{PhD}$.), Faculty of Metallurgy and Materials Engineering, the field of study Industrial control systems focusing on a quality control program. She is the author of interesting projects on the analysis in the field of the quality management system. In her professional work focuses on process improvement in services in the field of geology and the practical application methods of quality. She also aims at raising awareness of the importance of quality management system and the benefits of measuring and analytical instruments in the operative management of organizations.

E-mail: lajczykova.marketa@unigeo.cz 